\title{
Advancement of reproductive activity, seasonal reduction in prolactin secretion and seasonal pelage changes in pubertal red deer hinds (Cervus elaphus) subjected to artificially shortened daily photoperiod or daily melatonin treatments*
}

\author{
J. R. Webster and G. K. Barrell \\ Animal Sciences Group, Lincoln College, Canterbury, New Zealand
}

\begin{abstract}
Summary. Prepubertal red deer hinds were subjected to shortened daily photoperiod ( $8 \mathrm{~h}$ light per day, $\mathrm{N}=3$ ) or a daily (afternoon) melatonin injection $(\mathrm{N}=4)$ for 83 days starting on 8 January, 2 weeks after the summer solstice. Compared with control hinds $(\mathrm{N}=3$ ) these treatments caused premature moulting of summer pelage, reduced serum prolactin concentrations to barely detectable levels about 34 days earlier than usual and advanced the date of mating. Calves were born earlier $(P<0.005)$ in the hinds exposed to a shortened photoperiod (12 November \pm 1.7 days) and melatonin treatment (11 November \pm 3.2 days) than in control hinds ( 13 December \pm 7.9 days). Serum progesterone levels recorded before the first detected oestrus indicated that silent ovulations had occurred in many of the hinds (6 of 10$)$ in this experiment. This study demonstrated the role of shortened daily photoperiod in red deer and indicated that the effects of reduced photoperiod observed were mediated by melatonin.
\end{abstract}

\section{Introduction}

Manipulation of the photoperiod has been used successfully to induce a variety of physiological responses in animals. Artificial shortening of the daily photoperiod hastened the onset of puberty and altered the timing of pelage changes in white-tailed deer (Budde, 1983). Coat growth and moulting cycles in red deer stags have also been influenced by imposed lighting patterns (Kay \& Ryder, 1978). In sheep, reduction of the photoperiod advanced the onset of ovarian cyclicity (Walton, Evins, Fitzgerald \& Cunningham, 1980), stimulated testicular development (Lincoln \& Davidson, 1977) and reduced prolactin secretion (Walton et al., 1980) and wool growth (Morris, 1961). Photoperiodic effects on reproduction and other functions in sheep are mediated by the pineal gland, and the regulatory link between the pineal and many other organs may be provided by the putative pineal hormone, melatonin (Bittman, Dempsey \& Karsch, 1983). Daily melatonin administration has been an effective alternative treatment to shortened photoperiod for lowering serum prolactin concentration in ewes (Kennaway, Dunstan, Gilmore \& Seamark, 1982/83) and for inducing reproductive function in anoestrous ewes when given orally (Kennaway, Gilmore \& Seamark, 1982; Arendt, Symons, Laud \& Pryde, 1983) or intramuscularly (Nett \& Niswender, 1982). Similarly, oral administration of melatonin advanced ovarian cyclicity in red deer (R. Nowak, A. D. Crump \& R. G. Rodway, unpublished data) and advanced antler mineralization and pelage changes in white-tailed deer (Bubenik, 1983). 
We have examined the effects of shortened daily photoperiods or melatonin treatment on the onset of seasonal reproductive activity in pubertal red deer hinds.

\section{Materials and Methods}

Animals and experimental procedure. Prepubertal 13-month-old hinds were allocated to experimental groups: hinds in Group $1(\mathrm{~N}=3)$ were controls and experienced natural changes in photoperiod; 3 hinds in Group 2 were placed in a darkened room at 16:00 h each afternoon and released at $08: 00 \mathrm{~h}$ each morning (shortened daily photoperiod, see Text-fig. 1); and the other 4 hinds (Group 3) received an injection of melatonin $(3.75 \mathrm{mg}$ in safflower oil, i.m.) at 16:00 h each day. Hinds in Groups 1 and 2 received daily injections of the oil vehicle at the same time. Treatments began on 8 January (Day 1), 2 weeks after midsummer, and were continued until 31 March (Day 83). Two stags were used to mate the hinds although stag contact with the hinds was limited to $30 \mathrm{~min}$ each morning and evening so that all matings could be observed. To ensure that the stags would mate hinds before the natural breeding season, they too were subjected to the shortened daily photoperiod treatment but in a room separate from the hinds. The presence of motile spermatozoa in their ejaculates was confirmed on 11 March (Day 63).

During the calving period all hinds were observed twice daily to record the precise date of each calving.

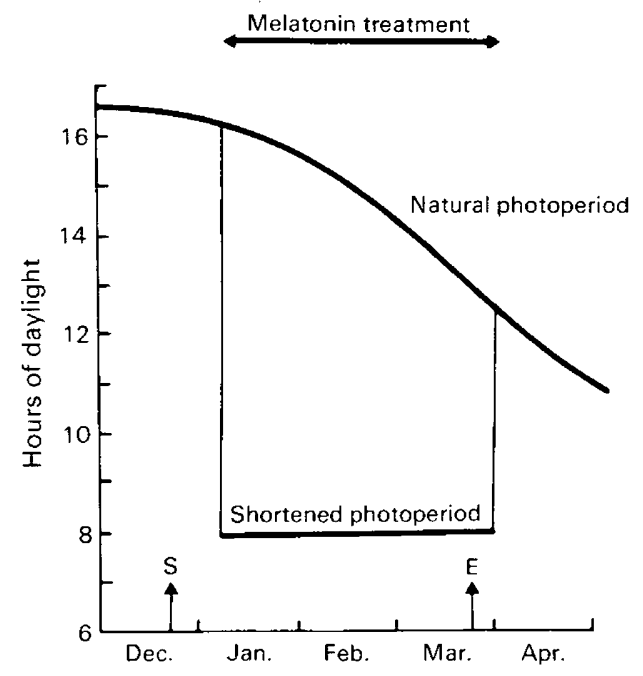

Text-fig. 1. Diagram showing hours of effective daylight (hours of daylight plus $60 \mathrm{~min}$ for Civil Twilight, at $43^{\circ} \mathrm{S}$ ) for both natura! (Groups 1 and 3 ) and shortened (Group 2) photoperiodic regimens to which pubertal red deer hinds were subjected during late summer and autumn. The duration of the daily melatonin injection procedure (Group 3 ) is indicated. Arrows denote the timing of the summer solstice (S) and autumn equinox (E).

Pelage. A visual inspection of the pelage of each hind was carried out on 9 March (Day 61).

Blood sampling and hormone assays. Jugular venous blood samples were collected from the hinds once each week and the serum was stored at $-20^{\circ} \mathrm{C}$ until radioimmunoassays were carried out for progesterone and prolactin.

The progesterone assay was similar to that described by Tungsubutra \& France (1978) and utilized a rabbit antiserum to progesterone-3-carboxymethyloxime-bovine serum albumin at a dilution of $1: 2500$. Steroids which cross-reacted in the assay were pregnanediol $(168 \%), 5 \alpha$ - 
pregnanedione $(117 \%)$, pregnenolone $(41 \%)$, deoxycorticosterone $(5 \cdot 1 \%), 17 \alpha$-hydroxyprogesterone $(1 \%)$ and testosterone $(0.5 \%)$. Cross-reactivities of oestradiol and corticosteroids were $<0.2 \%$. Since the progestagens with major cross-reactivity are present at very low levels in sheep plasma (Baird, McCracken \& Goding, 1973) a similar situation could be expected to apply in the case of deer serum. The minimum detectable level of progesterone in deer plasma was $0.99 \mathrm{nmol} / \mathrm{l}$. Mean within- and between-assay coefficients of variation were $0.45 \%$ and $18.6 \%$ respectively.

Prolactin was measured by the double-antibody procedure described by Barrell \& Lapwood $(1978 / 79)$ except that the serum samples were from deer and separation of antibody-bound from free tracer was carried out with goat anti-rabbit gamma globulin serum (Calbiochem). Iodinated ovine prolactin (NIH-ASP4328) was used as tracer and the antiserum, which was raised in rabbits against ovine prolactin, was diluted to $1: 50000$. There was no detectable cross-reactivity with up to $1 \mu \mathrm{g} / \mathrm{ml}$ of ovine GH, LH, FSH, TSH or ACTH in the assay system. Hormones or extracts of deer pituitary origin were not available for testing, but serum and plasma samples from stags or hinds produced inhibition curves which were parallel to those of the ovine standard (NIH-P-S12) in buffer. This assay therefore measures a prolactin-like immunoreactive material in deer serum and the results are expressed as ng NIH-P-S12 for convenience. Assay sensitivity was $1-2 \mathrm{ng} / \mathrm{ml} \mathrm{serum}$ and the within- and between-assay coefficients of variation were $9.2 \%$ and $13.7 \%$ respectively for a serum sample containing $72 \mathrm{ng} / \mathrm{ml}$. Recovery of ovine prolactin added to deer serum (1 occasion) and plasma ( 3 occasions) was always within $95 \%$ confidence limits of $100 \%$.

Statistical analysis. Mating and calving dates were analysed by 1-way analysis of variance. For serum prolactin data, l-way analysis of variance was performed for each week of sampling.

\section{Results}

\section{Pelage changes}

By Day 61, one of the 3 control hinds (Group 1) had partial moulting of its summer coat but the other 2 hinds were still in full summer pelage. All 3 hinds in Group 2 and 2 of the 4 in Group 3 were in full winter coat. The other 2 hinds in Group 3 had partly moulted their summer coats.

\section{Serum prolactin}

Serum prolactin concentration in all hinds declined from the high levels recorded at the beginning of the study to levels near the lower detection limit of the assay over the ensuing 3 months (Text-fig. 2). This decline was most rapid in the hinds in Groups 2 and 3, with values reaching baseline levels about 34 days (Day 41) before those of the controls (Day 75).

\section{Mating and calving dates}

Mating was advanced in Groups 2 and 3. Mean mating dates for Group 2 and Group 3 hinds were 23 March (Day $75 \pm 2.3$ days, s.e.m.) and 29 March (Day $81 \pm 3.4$ days) respectively, significantly earlier $(P<0.01)$ than in control hinds (Group 1) with a mean mating date of 24 April (Day $107 \pm 7.9$ days). Advancement of mating was reflected by significantly earlier calving dates for hinds in Groups 2 and 3 than in Group 1 ( 12 November $\pm 1 \cdot 7,11$ November $\pm 3 \cdot 2,13$ December \pm 7.9 , mean \pm s.e.m., respectively; $P<0.005$ ). All calves were born alive and without assistance after a gestation period of 230 days ( \pm 1.4 days, s.e.m.).

\section{Serum progesterone}

Each recorded mating was associated with a major elevation of progesterone secretion, indicative of at least one functional corpus luteum present after an overt oestrus. However, in 6 of 


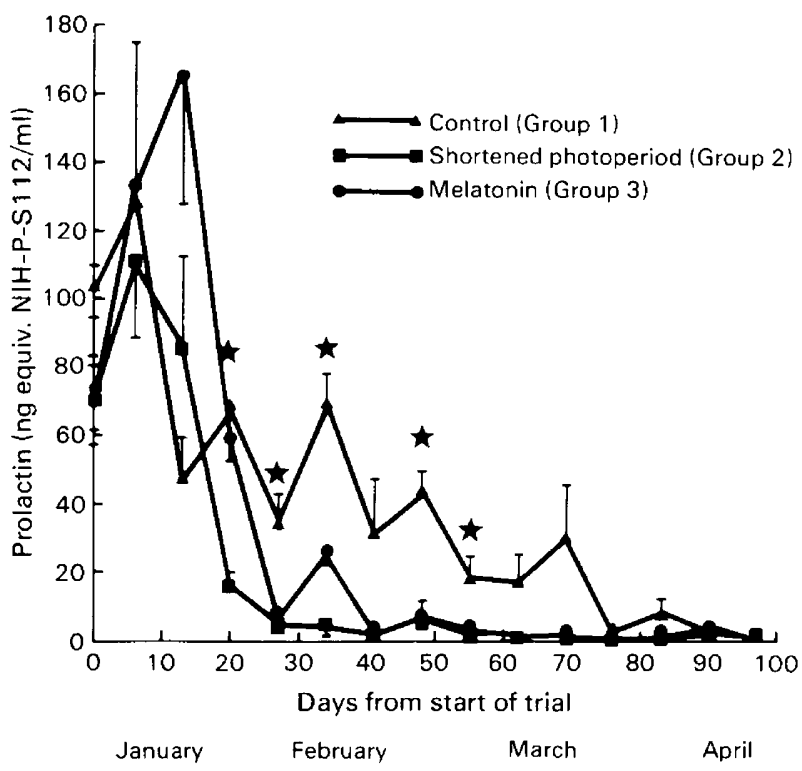

Text-fig. 2. Mean ( \pm s.e.m.) serum prolactin (ovine, NIH-P-S12) concentrations in pubertal red deer hinds subjected to melatonin treatment (Group 3, $N=4$ ), shortened daily photoperiod (Group $2, \mathbf{N}=3$ ) or natural daily photoperiods (Group 1, $\mathbf{N}=3$ ) during late summer and autumn. Asterisks indicate significant differences (1-way analysis of variance) between treatment groups $(P<0.01)$.

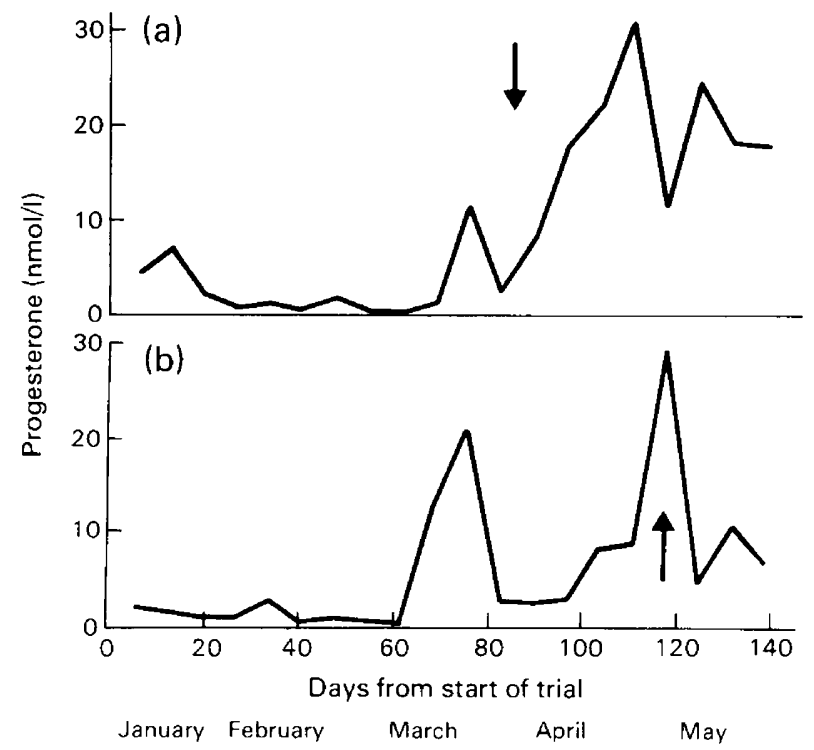

Text-fig. 3. Serum progesterone concentrations recorded at weekly intervals from a pubertal red deer hind in (a) Group 3, treated with melatonin and (b) Group 1 (control). These are typical examples from hinds in which elevated progesterone levels were recorded before mating. Arrows indicate the date when each hind was mated by a stag. 
the hinds ( 2 from each group) serum progesterone concentrations consistent with the presence of luteal tissue (Guinness, Lincoln \& Short, 1971) were detected in serum during the last 6 weeks before each hind's recorded mating (Text-fig. 3). There appeared to be no effect of treatment on the occurrence and timing of these elevations in progesterone concentration although the data were insufficient for any valid comparisons to be made. Serum progesterone levels after mating remained elevated, providing confirmation of pregnancy for each hind.

\section{Discussion}

These results demonstrate that all of the seasonal events in red deer which were monitored in this study were responsive to an early reduction in daily photoperiod. In addition, this effect of shortened photoperiod could be mimicked by administration of an appropriately timed daily dose of melatonin, a result which supports the existence of a regulatory role for the pineal gland in red deer hinds. Further studies will determine whether calving can be advanced earlier than 1 month as recorded here or whether this represents the limit that can be achieved by using these techniques.

Although we do not know the role of prolactin, its secretion is directly linked with photoperiod in sheep (Pelletier, 1973; Barrell \& Lapwood, 1979) and this study indicates the presence of a similar link in red deer. The fact that melatonin treatment was as effective as shortened photoperiods for lowering prolactin levels in serum suggests that photoperiod acts via melatonin to cause changes in prolactin secretion. There is no reason to suspect that the earlier reduction in serum prolactin levels in treated hinds recorded in this study had any direct effect on their earlier onset of mating activity. Reduction of prolactin secretion by using bromocriptine did not alter the onset of reproductive function in anoestrous ewes (Land, Carr, McNeilly \& Preece, 1980). In general, the pattern of prolactin secretion recorded from control hinds in this study agrees with that reported by Kelly, McNatty, Moore, Ross \& Gibb (1982), also for red deer hinds.

In this study we have obtained clear evidence for the existence of luteal function before the first recorded mating of 6 hinds. This observation establishes that the first pubertal ovulations in these hinds were 'silent', i.e. occurred without overt oestrus, whereas earlier reports had indicated a low incidence (Kelly \& Challies, 1978) or even tended to rule out the occurrence of silent ovulations in this species (Lincoln, Youngson \& Short, 1970; Guinness et al., 1971).

The mechanisms controlling puberty are considered to be identical to those regulating the annual onset of breeding (Foster \& Ryan, 1979). However, the response of pubertal hinds to the treatments utilized in this study cannot be translated immediately to adult hinds. First, adult hinds generally are lactating at the time of the treatment period of this experiment. Lactation in red deer can restrict the onset of breeding activity (Loudon, McNeilly \& Milne, 1983) and lactating red deer hinds do not respond to melatonin treatment (R. Nowak, A. D. Crump \& R. G. Rodway, unpublished data). Secondly, after adult hinds calve, involution of the uterus must place a finite limit on the shortness of the post-partum anovulatory period.

In conclusion we suggest that these results demonstrate some potential for use of melatonin to induce early calving in red deer. The major restriction on its use at present is the probable need for dosing at a specific time each day. Further work with melatonin is needed on dosage, route of administration, duration of treatment and on the timing of treatment. We consider that this study indicates considerable potential for melatonin as a biological tool which may prove of importance in commercial production from animals which are seasonal breeders.

We thank Mr M. Keeley for assistance with animal handling; Mrs C. Redekopp, Dr D. Fenemore and Dr P. A. Elder for assistance with the hormone assays; Dr D. F. M. van de Wiel, Research Institute for Animal Husbandry 'Schoonoord', The Netherlands, for prolactin antiserum; and Dr L. E. Reichert, Jr, The Albany Medical College, U.S.A., and National Institutes of Health, U.S.A., for hormone assay materials. 


\section{References}

Arendt, J., Symons, A.M., Laud, C.A. \& Pryde, S.J. (1983) Melatonin can induce early onset of the breeding season in ewes. J. Endocr. 97, 395-400.

Baird, D.R., McCracken, J.A. \& Goding, J.R. (1973) Studies in steroid synthesis and secretion with the autotransplanted sheep ovary and adrenal. In The Endocrinology of Pregnancy and Parturition, pp. 5-16. Ed. C. G. Pierrepoint. Alpha Omega Alpha, Cardiff.

Barrell, G.K. \& Lapwood, K.R. (1978/79) Seasonality of semen production and plasma luteinizing hormone, testosterone and prolactin levels in Romney, Merino and Polled Dorset rams. Anim. Reprod. Sci. 1, 213228.

Barrell, G.K. \& Lapwood, K.R. (1979) Effects of pinealectomy on the secretion of luteinizing hormone, testosterone and prolactin in rams exposed to various lighting regimes. $J$. Endocr. 80, 397-405.

Bittman, E.L., Dempsey, R.J. \& Karsch, F.J. (1983) Pineal melatonin secretion drives the reproductive response to daylength in the ewe. Endocrinology 113, 2276-2283.

Bubenik, G. (1983) Shift of seasonal cycle in white-tailed deer by oral administration of melatonin. $J$. exp. Zool. 225, 155-156.

Budde, W.S. (1983) Effects of photoperiod on puberty attainment of female white-tailed deer. J. Wildl. Mgmt 47, 595-604.

Foster, D. \& Ryan, K. (1979) Mechanisms governing onset of ovarian cyclicity at puberty in the lamb. Annls Biol. anim. Biochim. Biophys. 19, 1369-1380.

Guinness, F., Lincoln, G.A. \& Short, R.V. (1971) The reproductive cycle of the female red deer, Cervus elaphus L. J. Reprod. Fert. 27, 427-438.

Kay, R.N.B. \& Ryder, M.L. (1978) Coat growth in Red deer (Cervus elaphus) exposed to a day-length cycle of six months duration. J. Zool, Lond. 184, 505-510.

Kelly, R.W. \& Challies, C.N. (1978) Incidence of ovulation before the onset of the rut and during pregnancy in red deer hinds. N.Z. J. Zool. 5, 817-819.

Kelly, R.W., McNatty, K.P., Moore, G.H., Ross, D. \& Gibb, M. (1982) Plasma concentrations of LH, prolactin, oestradiol and progesterone in female red deer (Cervus elaphus) during pregnancy. J. Reprod. Fert. 64, 475-483.

Kennaway, D.J., Gilmore, T.A. \& Seamark, R.F. (1982) Effect of melatonin feeding on serum prolactin and gonadotropin levels and the onset of seasonal estrous cyclicity in sheep. Endocrinology 110, 1766-1772.

Kennaway, D.J., Dunstan, E.A., Gilmore, T.A. \& Seamark, R.F. (1982/83) Effects of shortened daylength and melatonin treatment on plasma prolactin and melatonin levels in pinealectomised and shamoperated ewes. Anim. Reprod. Sci. 5, 287-294.

Land, R.B., Carr, W.R., McNeilly, A.S. \& Preece, R.D. (1980) Plasma FSH, LH, the positive feedback of oestrogen, ovulation and luteal function in the ewe given bromocriptine to suppress prolactin during seasonal anoestrus. J. Reprod. Fert. 59, 73-78.

Lincoln, G.A. \& Davidson, W. (1977) The relationship between sexual and aggressive behaviour, and pituitary and testicular activity during the seasonal sexual cycle of rams, and the influence of photoperiod. $J$. Reprod. Fert. 49, 267-276.

Lincoln, G.A., Youngson, R.W. \& Short, R.V. (1970) The social and sexual behaviour of the red deer stag. $J$. Reprod. Fert., Suppl. 11, 71-103.

Loudon, A.S.I., McNeilly, A.S. \& Milne, J.A. (1983) Nutrition and lactational control of fertility in red deer. Nature, Lond. 302, 145-147.

Morris, L.R. (1961) Photoperiodicity of seasonal rhythm of wool growth in sheep. Nature, Lond. 190, 102-103.

Nett, T.M. \& Niswender, G.D. (1982) Influence of exogenous melatonin on seasonality of reproduction in sheep. Theriogenology 6, 645-653.

Pelletier, J. (1973) Evidence for photoperiodic control of prolactin release in rams. $J$. Reprod. Fert. 35, 143147.

Tungsubutra, V. \& France, J.T. (1978) Serial changes in plasma levels of progesterone, unconjugated oestradiol and unconjugated oestriol in normal pregnancy. N.Z. J. Obstet. Gynaec. 18, 97-103.

Walton, J.S., Evins, J.D., Fitzgerald, B.P. \& Cunningham, F.J. (1980) Abrupt decrease in daylength and short term changes in plasma concentrations of FSH, LH and prolactin in anoestrous ewes. $J$. Reprod. Fert. 59, 163-171. 